\title{
HUMAN RIGHTS IN ASIA: THE CASE OF CHINA, JAPAN AND NORTH AND SOUTH KOREA
}

\begin{abstract}
A bstract. This article presents the issue of human rights in selected East Asian countries: China, South and North Korea and Japan. The Author looks at them from the European perspective and try to analyse the same issue in different political systems in order to present it through the universal prism of Asian values. From an ethical perspective, some groups of Asian politicians and scientists perceive Asian values as the equivalent of human rights. The Bangkok Declaration of 1993 was a major step because it was the first to include Asian values in an international status document, and it emphasised their existence and historical and cultural difference to human rights. Human rights as a product of Western civilisation do not include the achievements and philosophical thoughts of the Asia region. The Author believes that human rights are universal, not because they concern all people and are universally respected and recognised - as claimed by most Western experts - but because they have been included in the constitutions of many countries of the world (formal recognition). In this sense, we can speak of some universalism of human rights.
\end{abstract}

Key words: Human rights; Asian values; China; Japan; Democratic People's Republic of Korea; Republic of Korea.

\section{INTRODUCTION}

The concept of human rights as we know it in Europe is foreign to the traditional reasoning of the Asian man. Different philosophical and religious systems, Confucianism in particular, partly shaped (depending on the state and the region) the models of society of many Asian countries. In this sense, the concept of human rights is perceived as a foreign, not fully understood and "imported" thought from the Western World. Also in modern Asian democracies human rights are not understood in the same way as in Europe.

LeCh BuczeK, PhD - John Paul II Catholic University of Lublin, Faculty of Humanities, Department of Sinology; email: lbuczek@kul.lublin.pl. ORCID: https://orcid.org/0000-0001-84464029 . 
What is more, the European system of human rights protection is the most developed and incomparable with the Asian system. The analysis covers two democratic countries - Japan (JAP) and the Republic of Korea (RoK), and two communist countries - the People's Republic of China (PRC) and the Democratic People's Republic of Korea (DPRK), though in both cases the countries significantly differ from each other.

The European system of human rights constitutes the most developed part of the world system of human rights protection. Others systems, such as Asian and African (though in the latter case it is hard to call it a real one), are underdeveloped both institutionally and in their practical implementation. The Asian system of human rights protection is based on global system documents, such as the International Covenant on Civil and Political Rights (1966), adopted by most of Asian countries. China signed the International Covenant on Civil and Political Rights but has not ratified it yet, and in 1997 the DPRK tried unsuccessfully to denounce the Covenant. The Bangkok Declaration of 1993, signed by over 40 countries (Stępień 24 and Wahyuningrum 13), is the only typical Asian document including the so-called "Asian values."

As part of the system there are only a few organizations such as LAWASIA (Law Association for Asia and the Pacific, 1966), including the Human Rights Committee (Jacobsen and Bruun 268) established within this organization in 1979. In 2009 the ASEAN Intergovernmental Commission on Human Rights (AICHR) was established and since 2011 it has been working on the ASEAN Human Rights Declaration (AHRD) (compare Wahyuningrum 2014 and AICHR).

From the European point of view, Asian countries, even the democratic ones, often violate different human rights. In my opinion, these are also violations of some of Asian values. If the countries follow them, they maintain political, economic and social stability but if they do not respect these values, the socio-political balance is disturbed.

One can thus ask why the system of human rights protection in Asia is less developed or just different? Are "Asian values" not the Eastern equivalent of the European concept of human rights? 


\section{ASIAN VALUES AND RECOGNITION OF HUMAN RIGHTS IN ASIA: THE PHILOSOPHICAL ASPECT}

The Asian concept of human rights comes from a different cultural background. It is understood differently, or understood in the Asian way. Asian values and human rights as understood by Europeans are two different issues. One may be tempted to say that human rights were "imported" to Asia in a similar way like Chinese tea was imported to Europe.

Generally, in the Asian way of thinking the family - and not the individual, is the lowest social unit entitled to rights which mirrors the collective way of thinking: acting for the good of the whole community and not of the individual, the community over individualism. The family is especially important - if there is harmony in it, then the state as a larger community can develop and prosper (Lasocka 433). Such ways of understanding the world derive from some of the largest religious and philosophical systems in Asia such as Taoism, Confucianism and various folk beliefs.

In Taoism man was never perceived in the category of an autonomous individual but as part of a collective (family, community, state) and the concept of a person as an individualistic creation is unknown in Asian philosophy (Kość 48). According to Antoni Kość, „Taoism does not attempt to derive the social order from the laws of nature; on the contrary, the order of nature is transferred onto human thinking and actions through good deeds, rites and meditation" (Kość 49).

Confucianism particularly emphasizes harmony, loyalty and subordination to the leader (political, business and religious), which are superior values over the individual freedom of a person. That is why the Asian man strictly and uncritically follows the orders of their superior. Any other, individualistic approach would mean disloyalty and noncompliance (Seligman 51). In the Confucian order everyone knows their place in the hierarchy and obeys it unquestioningly. According to Confucius the virtuous man Junzi 君子 is the one who follows the principle of loyalty zhong 忠, filial piety xiao 孝, benevolence ren 仁, affection $a i$ 愛, trustworthiness xin 信, righteousness $y i$ 義, harmony he 和 and peace ping 平 (Seligman 52).

According to Krzysztof Gawlikowski, in the Asian system of values three elements should be emphasized as regards the issue of human rights:

1) the collectivist understanding of the individual (which manifests itself in the marginalization of individualism, lack of the concept of freedom in Asian languages, the understanding of the individual as part of the whole, that is in duties of the individual towards society/the state); 
2) lack of legal tradition, especially related to the status of the individual in society (as opposed to the European Enlightenment thought which introduced subjective rights and the concept of the citizen; in Chinese tradition the law strictly regulated the vertical relation between the authority and the individual);

3 ) the functions and structure of the state and the attitude of society to the state (in contrast to Europe, where the state is associated with a potential restriction of individual freedom, in Asia the central authority was perceived as a defender rather than an oppressor) (Gawlikowski 10).

Confucianism also influenced the unequal treatment of women in Asian societies. The patriarchal system of distribution of tasks within society and the family is characteristic of Confucianism. Although there have been exceptions to this rule in history, traditionally in the family the oldest man ruled and therefore in Asia an exceptionally high importance was attached to having and educating a male descendant (Lasocka 434).

\section{THE PEOPLE'S REPUBLIC OF CHINA}

Despite spectacular economic successes and the impressive and fast growing army China is still a communist state with all its consequences in the field of human rights. Although China is a unique communist country, even for Asian conditions (with free market economy), like any other state with the communist system it does not give many civic rights. China is a state that refers to the communist ideas of Marxism and Leninism only formally in the Constitution (Dargas, Idee izasady 141). In economic terms, they introduced free market regulations, although many international actors, including the EU, have not yet recognized the Chinese economy as a formally free market (Cesarz and Klimowicz 116). Politically, much has changed since the Mao Zedong era. In their political practice the current authorities of Communist Party of China (CPC) are directed by pragmatism rather than ideology.

The worst situation is with the freedom of speech and religion (Human Rights Watch, China Events of 2017). Any instances of criticizing the authorities are punished in various ways including a death sentence, churches and denominations are persecuted, especially the Catholic Church. The Internet is censored and there is 50,000 Internet police (Hołdak and Konarzewska 290). 
A unique example of social discrimination is the "hukou system" which is still binding now, although in a modernized form. It is a kind of population register in which initially rural or urban origin was attributed to people. It was first introduced in China in 1951 as a tool used to control migration of people from rural to urban areas, and to control the movements of potential anti-communist activists (Chan 62). Over the years, this system has become more and more restrictive, covering the entire population and dividing it into rural and urban. Having an urban status in the hukou register gave measurable economic, social, cultural, societal and even marital benefits (Chan 63).

The current hukou system in China leads to multidimensional discrimination and exclusion of rural hukou people (Zhao 13). An even more significant division than the rural vs urban people is the regional division into hukou from the poorer and richer provinces as well as large and small cities, which discriminates people in terms of professional and social promotion.

"The one-child policy" introduced in China in 1979 was an example of gender-based discrimination (Żemło 13). Its purpose was to control the number of births: one could have only one child, preferably a male because girls after marriage entered their husband's family. If anyone had a bigger family, they could be fined or suffer other consequences (e.g. obstruction of professional career). Since 2016 Chinese officials have moved away from this policy, however its consequences remained.

Also in 1979 the first Criminal Code of the PRC was introduced and it limited the death penalty and introduced the institution of appeal against the judgment of a special court that allowed or rejected the appeal. In 1990 as part of the civil rights protection system a complaint was introduced which allowed citizens to challenge the decision of an administrative body, whereas from 1996 the length of detention was limited to one month and the role and position of the public defender was strengthened (Courtois, Paczkowski, Bartosek, Werth, Margolin and Panné 508).

Regular police did not carry firearms although a few years ago the authorities decided to provide police patrols with revolvers (Areddy and Wang). Cases of police brutality are very frequent. Criminal law still maintains the death penalty. Until 2008 it was performed by a shot in the head, now with an injection (Ufnowska). China and the DPRK come first as regards the number of executions but the details are kept secret (Osborne).

It would seem that due to the unique model of the "free-market economycommunist political system" Chinese citizens would enjoy economic rights and freedoms the most. It is not so. In 2013 China occupied the $140^{\text {th }}$ place 
according to the index of economic freedoms and currently the $110^{\text {th }}$, so there is an improvement, but the state control over private businesses still remains a problem (index of economic freedom 2018 and Raszewski 46).

China also suffers some international consequences of violations of human rights. Following the massacre of civilians in the Tiananmen Square, where about 100000 people were killed (Polit 336), the US and EU authorities imposed a number of sanctions on China, including the most severe, i.e. arms and technology embargoes (Kamieński 41 and Niewiadomski 148).

Officially, despite the formal recognition of human rights and their inclusion into the legal and political system of China, in practice these rights are respected only when they do not threaten the concept of the state, authority or ideology (Ahl 644). Until 1992 China signed several human rights conventions: the International Covenant on Civil and Political Rights (in 1998), International Convention on the Elimination of All Forms of Racial Discrimination of 21 December 1965, Convention on the Elimination of all Forms of Discrimination Against Women of 18 December 1979, Convention against Torture of 4 February 1985 and Convention on the Rights of the Child of 20 November 1989.

In international relations, especially with the EU, China emphasizes that they recognize the universality of human rights. Although China signed the International Covenant on Civil and Political Rights, they did not ratify it, therefore since 1995 the EU and China have held the Dialogue on Human rights and since 2007 the meetings of the EU-China Civil Society Round Table (Żodź-Kuźnia and Wiśniewski 79). However, China does not allow individual European leaders to dictate the resolution of human rights on their territory. Some of the EU member states, such as Germany, France and Italy, do not raise this issue in the meetings with Chinese delegations, for which they receive the most lucrative contracts (Morozowski 4; Żodź-Kuźnia and Wiśniewski 80).

In 2008 Liu Xiaobo, a human rights activists and co-creator of the Charter 08, was arrested for anti-state activities and sentenced to 11 years in prison (Xiaobo 152). The Chinese authorities strongly criticized the fact that Xiaobo was awarded the Nobel Peace Prize in 2010 (Liberska 246).

Despite the liberalizing reforms of Deng Xiaoping and the policies of $\mathrm{Hu}$ Jintao Xi Jinping aimed at reducing poverty and raising the standard of living of the average citizens, China still remains a state that repeatedly violates even basic human rights. Current actions of Xi are aimed at strengthening the political position of the head of the state and limiting any 
activities that could potentially lead to strengthening the rights of women and ethnic minorities, or accepting independent media (Young 266).

It is worth emphasizing that the instrumental approach to human rights in mainland China is also rooted in the concept of judicial systems. The judiciary is not independent. Local people's courts, the Supreme People's Court and the Supreme People's Procuratorate are controlled by the Communist Party of China (CPC) and only formally (in accordance with the provisions of the Constitution), they operate independently of other state authorities. (Veron 124). As a result the human rights are bent in order to achieve the various policy goals prioritized by the Chinese authorities.

\section{THE REPUBLIC OF KOREA}

The contemporary South Korean state is a democratic republic. The constitution guarantees all human rights. Citizens have political rights and enjoy the freedom of speech and religion. But it was not always like that. Since the proclamation of the Republic of Korea in 1948, army generals ruled and held the office of the president in an authoritarian manner. In the 1960s and 1970s the authorities violated human rights but at the same time they emphasised Confucian values, such as obedience and loyalty to own community, which were considered to be the foundation for building strong economy (Kightley 382).

The Korean War of 1950-1953 was the first humanitarian issue. It should be emphasized that all parties to the conflict were responsible for war crimes. The Bodo League massacre (Podoyonmaeng haksalsagon 보도연맹 학살사건) may be a good example of this. It was a war crime against communists and their sympathizers who were killed by South Korean and American soldiers in the summer of 1950 (Selden and Kim 1-8, and Chillil Hwahaerul Wihan'gwa Kosajongniwiwonhoe 진릴 화해를 위한과 거사정리위원회 72-81). The death toll was estimated between 100,000 and 200,000 (The San Diego Union-Tribune).

Another great humanitarian issue was connected with the post-war division of Korean families, whose number was initially estimated at 10 million (Dziak 120 and Rurarz 365). In spite of the meetings organized by the Red Cross Societies of North and South Korea over 80,000 citizens of South Korea did not have any contact with their relatives in the DPRK for almost 60 years (Lasocka 435). 
The Korean states decided to solve the problem of war-torn families during special negotiations conducted on $30^{\text {th }}$ August 1972 in Pyongyang (Burdelski, Czynniki warunkujace 40). During the negotiations in Seoul on $23^{\text {rd }}$ November 1972 the parties decided to create a special committee based in Panmunjom which would deal with finding and keeping records of members of divided families (Burdelski, Czy Korea będzie zjednoczona 16-18). On $1^{\text {st }}$ February 1982 a proposal was made to open a special passage in Panmunjom to enable meetings between divided families and on $29^{\text {th }}$ November 1984 the Red Cross introduced an initiative to reunite and identify family members and ensure the freedom of correspondence. One year later the biggest meeting of members of divided families took place-over 100 people in total (Burdelski, Czy Korea będzie zjednoczona 27). On 30 ${ }^{\text {th }}$ June 2000 an agreement was signed as regards the exchange of members of divided families and setting up a reunion centre for separated families. In 2003 an agreement was signed to establish the Mount Kumgang Reunion Centre (Buczek, Sprawa zjednoczenia państw koreańskich 127 and 139).

In the 1960s and 1970s there were many rebellions and protests. Mostly students protested but not only. Pro-democratic organizations were set up and were joined by representatives of different professions such as doctors, scientists, journalists and lawyers (Dargas, "Rola adwokatury" 348). The Catholic Church fully supported them in their fight for human rights. The Catholic Church and the Protestant Church in South Korea strongly and firmly opposed the dictatorship of President Park Chung-hee and Chun Doohwan (Snarski and Zawada 448). It needs to be emphasized that there was a great influence of Christianity on the democratization of this state because both believers and the authorities supported and co-organized pro-democratic organizations fighting for human rights (Buczek, Religia a polityka $w$ Korei 147).

After the introduction of the "Law on State Protection" in 1971 there were numerous student protests. Consequently, President Park Chung-hee introduced a state of emergency (Rurarz 378). Further protests, even bigger, broke out after introducing the Yushin constitution in 1972 and the parliamentary elections in 1979. All of them were bloodily suppressed (Rurarz 379-380). However, the most famous incident was the massacre of civilians in Gwangju in 1981. Initially, students protested against the coup d'état and the takeover of power by Gen. Chun Doo-hwan, then more protesters joined them. With the growing number of victims the spiral of hatred was growing bigger and bigger. The authorities used the army including special forces. It 
is estimated that the total number of victims ranged from 165 to over 2,000 and the number of injured amounted to almost 1,000 (Rurarz 384).

The Constitution of the Republic of Korea was amended nine times (Wiszowaty 329). The amendment of October 12, 1987 was very important for strengthening human rights protection because it not only extended the number of rights but also clarified them (Wiszowaty 328). Currently, all rights and civil duties are regulated in Chapter II of the Constitution (The Constitution of the Republic of Korea 6).

However, despite many political (amendments to the constitution) and democratic changes extending the actual scope of human rights, there are still instances of abuses. The sinking the Cheonan warship is a good example of this. Due to the proximity of the place of the sinking with the DPRK border the South Korean authorities initially considered four scenarios: a torpedo attack, a mine attack, an explosion inside the ship and hitting an underwater cliff (Pietrewicz). Most probably the Cheonan Corvette was sunk by a North Korean submarine on $26^{\text {th }}$ March 2010 (Bober 249). According to many Koreans the rescue operation was undertaken too late which reduced the chances of survival of potential survivors. Another issue was the concealment of the real causes of the Cheonan Sinking by the army. All of this caused a lot of criticism of the administration of President Lee Myung-bak. Consequently, the President in a special statement called on the DPRK authorities to take responsibility for the accident and imposed trade sanctions on North Korea (Burghart 61).

An even more flagrant example of human rights violation was the case of the sinking of the Sewol ferry. The ferry sank on $16^{\text {th }}$ April 2014 while carrying students from Incheon to Jeju. Among the victims there were 304 children and several divers from the rescue team. The situation was highly controversial and the families are still fighting for justice and compensation. The discussions on the causes of the catastrophe centre mostly on such factors as exceeding the capacity, negligence of safety procedures, abandoning the ship by the crew while the passengers were below deck, an inefficient rescue operation, an out-dated vessel, and informal collusion of a monopolist transport company, which prioritized profits over safety measures. The knowledge and consent of the central authorities made from Chonghaejin Marine Company Ltd. something similar to the Gwan-fia (관피아) or Hae-fia ("sea mafia") (You and Park 95-96 and 113-114).

South Korean police, apart from special task force teams, usually do not carry weapons (World Factbook of Criminal Justice Systems 6). In recent 
years no cases of extraordinary police brutality have been reported. The police carefully use the measures of direct coercion and the weapons are most often used in actions directed against organized crime groups. It is commonly believed that rigorous laws make the police fear to use force even in situations that require it (Jung).

Strong protests against President Park Geun-hye, who was controlled by a mysterious advisor Choi Tae-min, proved that South Korea is a full democracy. The Park-Choi affair led to the loss of confidence in power and political chaos and severely affected the image of Korea abroad (Tomański). Losing face by President Park justifies why traditional South Korean societieswhere one of the values is the respect for the authority, no longer obeyed this authority. During great demonstrations against the policies of President Park Geun-hye there were some cases of police brutality publicized by the antigovernment media. There was a renowned case of a 69 -year-old political activist, Baek Nam-gi, who died due to injuries caused by a police water cannon, received when he was protesting the rule of President Park Geun-hye (Shorrock). Further demonstrations connected with launching the impeachment procedure resulted in two more fatalities after police intervention. These events triggered the activation of pro-democratic organizations that united in the accusations against President Park Geun-hye. However, the allegations that South Korea is departing from democracy seem to be mainly political. A great number of protesters participated in demonstrations against Park Geun-hye and Baek Nam-gi was not at the best health due to his age, yet it does not change the fact that police brutality remains a problem.

Another issue is connected with controversies over the death penalty in the Republic of Korea. Despite the pressure of Amnesty International the death penalty is still retained in the Criminal Code, although in practice it has not been applied since 1998 and the ruling of President Kim Dea-jung (Amnesty International Global Report 9). Opponents of the death penalty raise the argument that it is incompatible with the Constitution. However, in 2010 the Constitutional Court of Korea ruled otherwise (Amnesty International).

\section{THE DEMOCRATIC PEOPLE'S REPUBLIC OF KOREA}

The DPRK is one of the world's leading countries that repeatedly violate human rights. Although basic human rights are guaranteed in the Constitution, the reality is quite different. 
The catastrophic humanitarian situation of the DPRK citizens is a result of the Kim dynasty regime. It is very difficult to unambiguously classify the very system of the state because it has the characteristics of both totalitarianisms - communism and fascism, other authoritarianisms and military systems, and the original state ideology called Juche.

Although the Confucian mentality remained in the minds of the Koreans due to its long history, Juche is the only permitted ideology and religion because other religions are persecuted. The Constitution includes a provision on the freedom of religious beliefs, but this right is not respected. According to Art. 68, Chapter 5 of the Constitution churches and religious associations may operate as long as they do not threaten the social order. The provision is constructed in such a way that it allows persecution of any religion. The Christians living in Korea are in a particularly difficult situation. Right after the Korean war the Kim Il-sung regime accused them of collaboration with the UN and under Kim Jong Il open persecutions began. The public declaration of the Christian faith or the very fact of having a Bible is punished with the death penalty or camp (Buczek, Religia a polityka $w$ Korei 140-141). According to Open Doors Organization the DPRK is still first among the states that persecute Christians the most (Open Doors, Christan Persecution World Watch List).

Juche ideology is based on the concept of self-reliance according to which North Korea is independent in politics, self-sufficient in economy and self-reliant in defence and in every other respect from the outside world. Interestingly, Juche puts the person in the centre of interest which, given the practice of violating fundamental human rights, is most bizarre. As Kim Jong Il explains: "The Juche idea is a new philosophical thought which centres on man. As the leader [i.e. Kim Ir Sen] said, the Juche idea is based on the philosophical principle that man is the master of everything and decides everything" (Kim; Dziak 235-236).

Officially, equality does not exist - in the early years after the proclamation of the DPRK citizens were divided into 51 classes (categories). However, in practice this system was so complex that in the 1980s it was limited to 3 classes: hostile (subject to punishment and resocialization), core (citizens in the service of the state) and wavering (people who can become representatives of the former or the latter class) (Courtois, Paczkowski, Bartosek, Werth, Margolin, and Panné 527).

Reactionary statements, slandering the party and the leader are all punishable by the death penalty. The old Code of 1990 rejected the principle of 
nulla poena sine lege but it was introduced to the 2004 amendment, at the same time increasing penalties for espionage and treason (Dziak 258; Guzowski 144). As far as the numerical data of executions is concerned it is difficult to be accurate due to a large number of "unofficial executions". The death penalty is usually by shooting but even more people are killed in labour camps for political prisoners.

The DPRK is one of the last countries in the world which have concentration camps, also called death camps. It is estimated that there are between 150,000 and 200,000 prisoners in these camps. They are located in such places as Yodok, Kaechon, Hoeryong, Chongjin and others (Dziak 265). The camps are divided into several types. Kwalliso are labour camps for political prisoners, sent there for crimes against the authorities and the state together with the immediate three generation of their family members (it is a form of collective punishment because of family association). They are often imprisoned on the basis of denunciation, without trial and after pleading guilty forced by torture. The second type is Kyohwaso - these are re-education camps where people are placed for a limited period of time for committing criminal offences. The last types are Kamok and Kuryujang where people subjected to forced repatriation from China are put and interrogated after an unsuccessful escape from the DPRK (Guzowski 147-149). After determining the motives of their escape such people may be sent to other camps, e.g. Kwalliso and serve a life sentence together with their family.

Political rights are fiction. In practice people take part in the elections to the Supreme People's Assembly but they can only support the previously selected representatives. If they vote "no" or boycott the elections, they face punishment for anti-state actions and are sent to a camp (Dziak 259). There is a number of serious problems connected with violation of social rights, such as hunger, forced labour, lack of freedom of movement, discrimination against the disabled. At the end of the 1990s the country suffered the greatest famine due to the cumulation of various factors, including extremely bad agricultural policy, a crisis in political and commercial relations with Russia after the collapse of the USSR and a number of natural disasters (floods and droughts in years 1994-1995 and 1997). Due to the isolation of the state and the DPRK propaganda, there is no reliable data on humanitarian consequences, however according to the World Health Organization (WHO) experts there might be hundreds of thousands of famine victims (Courtois, Paczkowski, Bartosek, Werth, Margolin, and Panné 530). 
Earnings are meagre and until the 1990s payment in kind was used. Food rations depended on the social status, position in a party or army resulted in additional profits (Dziak 260). Even now the food and material situation of army members is better than the average person, which reflects the Songun policy, that is the "military first". The DPRK is the most militarized country in the world and military expenditure amounts to $20-25 \%$ of the state income. The Korean People's Army has 1 million active soldiers, which gives it the fourth place in the world, and a further 7.7 million in reserve (both men and women have to undergo a 10-year military service). As a result, this small country has the world's fourth largest army (Pacuła, "Przyszłość Korei Północnej” 184).

In addition, there is a problem of the exploitation of Korean workers abroad. It is officially known that at least four of the EU member states (Poland, the Czech Republic, Romania and Bulgaria) employs such workers and pay them much lower salaries, which in most cases go to the State Treasury (Bober 127).

As for a country with such a small area and population, the number of victims of the North Korean regime is exceptionally high and, according to The Black Book of Communism, amounts to 2 million (Courtois, Paczkowski, Bartosek, Werth, Margolin, and Panné 25). It is worth adding that the activities of the DPRK regime affect not only its citizens. There have also been instances of kidnappings of Japanese citizens or arrests and imprisonment of citizens of other countries, most often the United States. In 1956 several hundred Japanese women, who entered the DPRK territory with their Korean husbands, in most cases never left the country. Their fate is not fully known but the accounts of refugees from labour camps suggest that some of these women were sent to such camps. Both Japan and Amnesty International have repeatedly called for their release. In 1996 there was a renowned case of eliminating a South Korean diplomat by the North Korean special forces in Vladivostok (Courtois, Paczkowski, Bartosek, Werth, Margolin, and Panné 528). Another issue was connected with numerous detentions of the US citizens. The first of them was Evan Hunziker, arrested in 1996 and accused of espionage. Next, in 2009 journalists Laura Ling and Euna Lee, who worked on a report on refugees from the DPRK, were both arrested but released after the US diplomatic offensive. Then in 2004 Jeffrey Edward Fowle was arrested for smuggling the Bible but was released the same year. Finally, in 2016 Otto Warmbier was arrested and sentenced for anti-state activities to 15 years of hard labour. In 2017 he was released but died a few days after returning to the US (Husarski). 


\section{JAPAN}

Although contemporary Japan is a monarchy, and more precisely a constitutional monarchy with a parliamentary system of government, it is not a Western-like democracy. The Constitution of 1947 guarantees human rights and is called American, though in terms of its structure and content it is modelled on European constitutions (Bernaczyk and Muszalska 70). As early as in the 1889 Meiji Constitution human rights were included, however they were treated as "a gentle gift of the Emperor to the subjects" (Bernaczyk and Muszalska 73-74). Although the current constitution recognizes the formal superiority of an individual over the state, in practice the good of the state is put before the well-being of citizens, and state secrets over the right to information (Bernaczyk and Muszalska 74 and 77). Even today, there are many cases of violations of various human rights.

Historically, Japan can be accused of much in the field of human rights. Japanese imperialism and the aggressive policy of annexing particular countries resulted in many victims. First, there was Korea in 1910.

The Japanese occupation of Korea was characterized by cruelty, economic exploitation and the destruction of culture (Rurarz 329). One example may be the events at the turn of March and April 1919. The Japanese suppressed the protests of Koreans who, after the death of King Gojong, proclaimed the Declaration of Independence. All possible coercive measures against protesters were taken, including the army, and 7509 Koreans were killed (Rurarz 333).

The next victims of aggressive policy are Manchuria and the northern territories of China. It started with the Mukden Incident in 1931 (the invasion of Manchuria) and then in 1937 there was the Marco-Polo Bridge Incident which triggered the First Chinese-Japanese War (Wardęga 229). A blatant example of crimes against humanity was the Nankana massacre which started on $13^{\text {th }}$ December 1937 and lasted for a few weeks during which civilians were murdered and women raped. According to various sources 340,000 people were killed and 80,000 women were raped (Wardęga 233).

Another issue was connected with the so-called "comfort women" and involved these parts of Asia where the Imperial Japanese Army operated. The Japanese authorities created a network of front-row public houses where women, mostly Korean and Chinese (but also Filipinos, Thai and even Dutch), were forced to provide sexual services for Japanese soldiers 
(Wardęga 236). In 2000 Women's International War Crimes Tribunal on Japan's Military Sexual Slavery was set up (Chinkin 335).

The most telling was the strategy of General Yasuji Okamura called the Three Alls Policy (kill all, burn all and loot all) which resulted in almost 2,7 million of dead Chinese in the territory occupied by the Imperial Japanese Army (Pacuła, "Relacje Chin" 80). It should be emphasized that the Japanese authorities did not officially take responsibility for the crimes committed by the imperial army during World War II. It is well exemplified by the case of the Yasukuni Shrine. It is a Shinto shrine built in 1869 which is still one of the main centres of this religion in Japan. The greatest controversies were aroused by the fact that this place commemorated the souls (Jap. kami 神) of Japanese soldiers fighting on various fronts who were recognized war criminals by the international public and the International Military Tribunal for the Far East. Initially, Yasukuni commemorated the souls of imperial soldiers who died in military actions in the Boshin War (1868-1869), then Taiwanese, Koreans and civilians who died in service of Japan. At present, there are about 2,5 million of names in the Book of Souls - most of them are soldiers who died during World War II (Wardęga 239-241). The official visits of the Japanese authorities to the Yasukuni Shrine always arouse huge protests in China, Korea and other countries of the region.

Contemporary Japan is defined as a democratic state of law but the individual-state relationship remains typical for Asian values. Japanese policemen are regularly equipped with firearms, although after World War II it was different (Takemae 58). Cases of police brutality are frequent but the use of firearms during police interventions is very rare.

The most serious crimes are punishable by death by hanging. The majority of society supports this state of affairs claiming that strict penitentiary system and the death penalty keep the scale of crime small ("Japonia: surowe więzienie i kara śmierci”).

Currently, according to Human Watch reports, most cases of human rights violation in Japan concern the disregard of workers' rights, in particular excessive exploitation of employees like failure to adhere to the working time standards, failure to pay overtime and holiday in arrears (Human Rights Watch, Japan Events of 2016). 


\section{CONCLUSION}

Asian values modify the concept of human rights universalism. Despite their systemic diversity, Asian countries are based to a greater or lesser extent on the so-called "Asian values" which are not fully comprehensible to the Western world. It may also be the reason why Western political scholars call Asian democracies soft authoritarianism (Goban-Klas 210). Regardless of the political system, Asian countries differently perceive what Europeans call human rights. This was reflected in the Bangkok Declaration of 1993 which codified Asian values constituting ethical and moral determinants of action and functioning in an international, intra-state and interpersonal environment.

\section{BIBLIOGRAPHY}

\section{SOURCES OF LAW}

ASEAN Intergovernmental Commission on Human Rights, aichr.org/. Accessed 1.06.2020.

Chillil Hwahaerul Wihan'gwa Kosajongniwiwonhoe 진릴 화해를 위한과 거사정리위원회 (Truth and Reconciliation Commission. Republic of Korea), Report Activities of the Past Three Years, Seoul 2009.

China Events of 2017, "Human Rights Watch", www.hrw.org/world-report/2018/country-chapters/ china-and-tibet. Accessed 1.06.2020.

Convention against Torture and Other Cruel, Inhuman or Degrading Treatment or Punishment New York, 10 December 1984. United Nations Treaty Collection, treaties.un.org/ pages/ ViewDetails.aspx?src=IND\&mtdsg_no=IV-9\&chapter=4\&lang $=$ en. Accessed 1.06.2020.

Convention on the Elimination of all Forms of Discrimination Against Women of 18 December 1979. United Nations Treaty Collection, treaties.un.org/Pages/ViewDetails.aspx?src= TREATY \&mtdsg_no=IV-8\&chapter=4\&lang=en. Accessed 1.06.2020.

Convention on the Rights of the Child of 20 November 1989. United Nations Human Rights Office Of The High Commissioner, www.ohchr.org/en/professionalinterest/pages/crc.aspx. Accessed 1.06.2020.

International Convention on the Elimination of All Forms of Racial Discrimination of 21 December 1965, www.ohchr.org/en/professionalinterest/pages/cerd.aspx. Accessed 1.06.2020.

Japan Events of 2016. "Human Rights Watch", www.hrw.org/world-report/2017/country-chapters/ japan. Accessed 1.06.2020.

The Constitution of the Republic of Korea. www.wipo.int/edocs/lexdocs/laws/en/kr/kr061en.pdf. Accessed 1.06.2020.

\section{SECONDARY LITERATURE}

Ahl, Björn. "The Rise of China and International Human Rights Law." Human Rights Quarterly, vol. 37, 2015, pp. 637-661, doi: 10.2139/ssrn.2830215.

Amnesty International Global Report, "Death sentences and executions in 2016," www.amnesty.org/ download/Documents/ACT5057402017ENGLISH.PDF. Accessed 1.06.2020. 
Areddy, James T., and Fanfan Wang. "China's Police Will Carry Guns Unlike Any Others." The Wall Street Journal 2014, April 24, blogs.wsj.com/chinarealtime/2014/04/24/chinas-policewill-carry-guns-unlike-any-others/. Accessed 1.06.2020.

AS. "Japonia: surowe więzienie i kara śmierci skutecznie odstraszają przestępców." Polonia Christiana, March 28, 2013, www.pch24.pl/japonia--surowy-wiezienie-i-kara-smierci-skute cznie-odstraszaja-przestepcow,13673,i.html. Accessed 1.06.2020.

Bernaczyk, Michał, and Urszula Muszalska. "Ewolucja prawa do informacji w Japonii. Od shiru kenri do Joho Kokai Ho." Aktualne wyzwania ochrony wolności i praw jednostki, edited by Mariusz Jabłoński and Sylwia Jarosz-Żukowska, E-Wydawnictwo. Prawnicza i Ekonomiczna Biblioteka Cyfrowa. Wydział Prawa, Administracji i Ekonomii Uniwersytetu Wrocławskiego, 2014, pp. 67-86.

Bober, Andrzej. Korea zjednoczona - szansa czy utopia? Wydawnictwo KWIAT ORIENTU, 2013.

Buczek, Lech. "Religia a polityka w Korei." Religia w polityce światowej. Dylematy narodowe i międzynarodowe, edited by Wojciech Gizicki, Instytut Sądecko-Lubelski, 2013, pp. 139-149.

Buczek, Lech. Sprawa zjednoczenia państw koreańskich. Studium prawnomiędzynarodowe. Unpublished doctoral thesis. The John Paul II Catholic University of Lublin, 2010.

Burdelski, Marceli. Czy Korea będzie zjednoczona do końca XX wieku? Wydawnictwo ADAM MARSZAŁEK, 1995.

Burdelski, Marceli. Czynniki warunkujące proces podziału i zjednoczenia Korei. Wydawnictwo ADAM MARSZAŁEK, 2004.

Burghart, Sabine. "Relations Between the Two Koreas in 2010." Korea: Politics, Economy and Society, edited by Frank Rüdiger, Jim Hoare, Patrick Köllner, and Susan Pares, Brill, 2010, pp. 59-70.

Cesarz, Maciej, and Monika Klimowicz. "Stosunki gospodarcze Unii Europejskiej z Chinami. Wybrane aspekty współpracy gospodarczej w świetle uwarunkowań prawnych do 2005 roku." Wspótczesne Chiny w kontekście stosunków międzynarodowych, edited by Joanna Wardęga, Wydawnictwo Uniwersytetu Jagiellońskiego, 2013, pp. 99-119.

Chan, Kam Wing. “China's Hukou System at 60: Continuity and Reform.” Handbook on Urban Development in China, edited by Ray Yep, Jun Wang, and Thomas Johnson, Edward Elgar Publishing, 2018, pp. 59-79.

Chinkin, Christine M. "Women's International Tribunal on Japanese Military Sexual Slavery." The American Journal of International Law, vol. 95, no. 2, 2001, pp. 335-341, doi: $10.2307 / 2661399$.

Courtois, Stéphane, Andrzej Paczkowski, Karel Bartosek, Nicolas Werth, Jean-Louis Margolin, and Jean-Louis Panné. Czarna księga komunizmu. Zbrodnie, terror, prześladowania. Translated by Krzysztof Wakar, Andrzej Nieuważny, and Blanka Panné, Proszyński S-ka, 1999.

Dargas, Marta. „Rola adwokatury w wymiarze sprawiedliwości Korei Południowej.” Korea w oczach Polaków. Państwo - Społeczeństwo - Kultura, edited by Józef Włodarski, Kamil Zeidler, and Marceli Burdelski, Wydawnictwo Uniwersytetu Gdańskiego, 2012, pp. 345-356.

Dargas Marta. Idee i zasady konstytucyjne Chińskiego porzadku prawnego. Wydawnictwo C.H. Beck, 2017.

Dziak, Waldemar Jan. Korea Pokój czy wojna. Świat Książki, 2003.

Dzong Il Kim. O Ideach Dżucze w naszej partii. Wydawnictwo literatury w językach obcych, 1988. 
Gawlikowski, Krzysztof. "Problem człowieka z perspektywy azjatyckiej." Azja-Pacyfik. Społeczeństwo. Polityka. Gospodarka, vol. 1, 1998, pp. 9-52.

Goban-Klas, Tomasz, Korea. Historia i wspótczesność. Od pustelniczego królestwa do azjatyckiego tygrysa. Wydawnictwo ADAM MARSZAŁEK, 2006.

Guzowski, Adam. "Obozy koncentracyjne w Korei Północnej." Korea w oczach Polaków. Państwo - Społeczeństwo - Kultura, edited by Józef Włodarski, Kamil Zeidler, and Marceli Burdelski, Wydawnictwo Uniwersytetu Gdańskiego, 2012, pp. 143-162.

Hołdak, Katarzyna, and Anna Konarzewska. "Stosunki Unii Europejskiej z Chinami." Bezpieczeństwo Narodowe, vol. 3-4, no. 5-6, 2007, pp. 278-300.

Husarski, Roman. "Temida z Korei Północnej.” Centrum Studiów Polska-Azja (CSPA), July 8, 2016, www.polska-azja.pl/temida-z-korei-polnocnej/. Accessed 10.05.2018.

Jacobsen, Michael, and Ole Bruun. Human Rights and Asian Values: Contesting National Identities and Cultural Representations in Asia. Curzon Press, 2000.

Kamieński, Tomasz. "Miejsce Chin w polityce bezpieczeństwa Unii Europejskiej." Azja-Pacyfik. Społeczeństwo. Polityka. Gospodarka, no. 9, 2006, pp. 30-48.

Kightley, Marta, "Południowokoreański cud gospodarczy w świetle koncepcji człowieka gospodarującego." Korea w oczach Polaków. Państwo - Społeczeństwo - Kultura, edited by Józef Włodarski, Kamil Zeidler, and Marceli Burdelski, Wydawnictwo Uniwersytetu Gdańskiego, 2012, pp. 369-386.

"Korea Południowa: kara śmierci zgodna z Konstytucją." Translated by Przemek Basaj. Amnesty International”, February 25, 2010, amnesty.org.pl/korea-po\%C5\%82udniowa-kara-\%C5\%9 Bmierci-zgodna-z-konstytucj\%C4\%85/. Accessed 1.06.2020.

Kość, Antoni. Prawo a etyka konfucjańska w historii myśli prawnej Chin. Pracownia Poligraficzna przy Prywatnym Liceum Ogólnokształcącym, 1998.

Lasocka, Dagmara. "Religia i tradycja. Filary koreańskiej rodziny." Korea w oczach Polaków. Państwo - Społeczeństwo - Kultura, edited by Józef Włodarski, Kamil Zeidler, and Marceli Burdelski, Wydawnictwo Uniwersytetu Gdańskiego, 2012, pp. 431-441.

LAWASIA. The Law Association for Asia and the Pacific, www.lawasia.asn.au/home.html. Accessed 1.06.2020.

Liberska, Barbara. "Perspektywy rozwojowe chińskiej gospodarki do 2050 roku." Studia Ekonomiczne, n. 4 (67), 2010, pp. 331-358.

Mei-Ying Hung, Veron. “China's WTO Commitment on Independent Judicial Review: Impact on Legal and Political Reform." American Journal of Comparative Law, vol. 52, issue 1, 2004 , pp. 77-132, doi: 10.2307/4144447.

Min-ho, Jung. "Police guns just for show." The Korean Times, May 22, 2018, www.koreatimes. co.kr/www/nation/2018/05/251_249378.html.

Morozowski, Tomasz. "Polityka Niemiec wobec Chin." Biuletyn Instytutu Zachodniego, no. 274, 2016, iz.poznan.pl/plik,pobierz,1697,db671d8112b0182beb21a9c492c99671/274ChinyNiemcy.pdf. Accessed 1.06.2020.

Niewiadomski, Łukasz. "Stosunki chińsko-rosyjskie i ich wpływ na świat.” Bezpieczeństwo Narodowe, vol. 1, no. 1, 2006, pp. 143-156.

Open Doors. Christian Persecution World Watch List 2018, www.opendoors.org.za/christianpersecution/world-watch-list-2018/. Accessed 1.06.2020. 
Osborne, Samuel. "Which countries still have the death penalty - and who executes the most prisoners?" Independent, 10 December 2016, www.independent.co.uk/news/world/death-penaltyexecutions-which-countries-have-kill-most-prisoners-a7354301.html. Accessed 1.06.2020.

Pacuła, Przemysław. "Przyszłość Korei Północnej.” Bezpieczeństwo Narodowe, vol. 3-4, no. 2324, 2012, pp. 181-199.

Pacuła. Przemysław. "Relacje Chin z wybranymi państwami w Azji Południowo-Wschodniej i Wschodniej." Bezpieczeństwo Narodowe, no. 2, 2015, pp. 77-99.

Petersen, Carole J. "Bridging the Gap?: The Role of Regional and National Human Rights Institutions in the Asia Pacific." Asian-Pacific Law \& Policy Journal, vol. 13, issue 1, 2011, pp. 174-209.

Pietrewicz, Oskar. "Tajemnice zatonięcia korwety Cheonan." Portal Spraw Zagranicznych, 29 March 2010, www.psz.pl/124-polityka/oskar-pietrewicz-tajemnice-zatoniecia-korwety-cheonan. Accessed 1.06.2020.

Polit, Jakub Jarosław. Chiny. Historia państw świata w XX wieku. Wydawnictwo TRIO, 2004.

Raszewski, Adam. "Human rights in China and the philosophical perspective." Acta Asiatica Varsoviensia, no. 28, 2015, pp. 39-49.

Rurarz, Joanna J. Historia Korei. Wydawnictwo DIALOG, 2009.

Selden, Mark, and Kim Dong-choon. "South Korea's Embattled Truth and Reconciliation Commission." The Asia-Pacific Journal, vol. 8, no. 4, 2010, pp. 1-8.

Seligman, Scott, D. Chinese Business Etiquette: A Guide to Protocol, Manners, and Culture in the People's Republic of China. Warner Books, 1999.

Shorock, Tim. "The South Korean Government Is Steadily Eroding Democratic Freedoms." The Nation, 2 June 2016, www.thenation.com/article/the-south-korean-government-is-steadilyeroding-emocratic-freedoms/. Accessed 1.06.2020.

Snarski, Tomasz, and Jarosław Zawada. "Chrześcijaństwo w Korei - pomost między Azją a Europą." Korea w oczach Polaków. Państwo - Społeczeństwo - Kultura, edited by Józef Włodarski, Kamil Zeidler, and Marceli Burdelski, Wydawnictwo Uniwersytetu Gdańskiego, 2012, pp. 443-450.

Stępień, Mateusz. "Deklaracja Bangkocka - azjatycki głos w sprawie praw człowieka." Annales Universitatis Mariae Curie-Skłodowska. Sectio K: Politologia, vol. 17, no. 1, 2010, pp. 23-31.

Takemae, Eiji. "History of the non-military activities of the Occupation of Japan, 1945-1951." Constitutional Revision, no. 15, 2000, pp. 41-59.

The Heritage Foundation, "2018 Index of Economic Freedom 2018”. www.heritage.org/ index/country/china. Accessed 1.06.2020.

The San Diego Union-Tribune, www.sandiegouniontribune.com/sdut-korea-bloodbath-probe-ends us-escapes-much-blame-2010jul10-story.html. Accessed 1.06.2020.

Tomański, Rafał. "O skandalu z udziałem prezydent Korei Południowej." Rzeczpospolita, 31 December 2016.

Ufnowska, Izabela. "Kara śmierci w Chinach.” Peoples Square, 20 April 2016, peoplessquare.pl/ 2016/04/20/kara-smierci-w-chinach/. Accessed 1.06.2020.

Wahyuningrum, Yuyun. "AICHR After Five Years: Progress, Challenges and Opportunities." FOCUS, vol. 76, 2014, www.hurights.or.jp/archives/focus/section3/2014/06/aichr-after-fiveyears-progress-challenges-and-opportunities.html. Accessed 1.06.2020. 
Wardęga, Joanna. "Wykorzystanie dyskursu historycznego w chińsko-japońskiej konkurencji o przywództwo w Azji Wschodniej - perspektywa chińska." Współczesne Chiny w kontekście stosunków międzynarodowych, edited by Joanna Wardęga, Wydawnictwo Uniwersytetu Jagiellońskiego, 2013, pp. 229-248.

Wiszowaty, Marcin Michał. "System ustrojowo-polityczny VI Republiki Korei." Korea w oczach Polaków. Państwo - Społeczeństwo - Kultura, edited by Józef Włodarski, Kamil Zeidler, and Marceli Burdelski, Wydawnictwo Uniwersytetu Gdańskiego, 2012, pp. 327-344.

World Factbook of Criminal Justice Systems: South Korea, 4 August 2007, www.bjs.gov/ content/pub/pdf/wfbcjssk.pdf. Accessed 1.06.2020.

Xiaobo, Liu. “Two Essays on China's Quest for Democracy.” Journal of Democracy, vol. 22, no. 1, 2011, pp. 152-166.

You, Jong-sung, and Min Park Youn. "The Legacies of State Corporatism in Korea: regulatory capture in the Sewol ferry tragedy." Journal of East Asian Studies, vol. 17, issue 1, 2017, pp. 95-118, doi: $10.1017 /$ jea.2016.32.

Young, Stephen. "U.S.-China Relations." American Foreign Policy Interests. The Journal of the National Committee on American Foreign Policy, vol. 37, issue 5-6, 2015, pp. 264-272, doi: 10.1080/10803920.2015.1162064.

Zhao, Laixun. A Simple Model of the Chinese Hukou System and Some Ongoing Reforms. Research Institute for Economics \& Business Administration, 2017.

Żemło, Aleksandra. Wspótpraca gospodarcza jako element partnerstwa strategicznego Unia Europejska - Chińska Republika Ludowa. Master thesis. Warsaw University, 2013.

Żodź-Kuźnia, Katarzyna, and Janusz Wiśniewski. "Dynamika wzajemnych relacji między Unią Europejską a Chińską Republiką Ludową na początku XXI wieku.” Przegląd Politologiczny”, no. 2, 2012, pp. 65-84, doi: 10.14746/pp.2012.17.2.5.

\section{PRAWA CZŁOWIEKA W AZJI \\ NA PRZYKŁADZIE CHIN, JAPONII I PAŃSTW KOREAŃSKICH}

\section{Streszczenie}

Artykuł stanowi analizę zagadnienia praw człowieka w Azji na przykładzie wybranych państw regionu: Chińskiej Republiki Ludowej, Republiki Korei, Koreańskiej Republiki Ludowo-Demokratycznej i Japonii. W artykule przedstawiono problematykę praw człowieka „Z europejskiej perspektywy", nie pomijając jednocześnie koncepcji wartości azjatyckich, uniwersalnych dla regionu Azji Wschodniej. W tym celu analizie zostały poddane państwa o różnych ustrojach politycznych.

Zdaniem części azjatyckich ekspertów i polityków wartości azjatyckie mogą być ekwiwalentem zachodniej koncepcji praw człowieka. W tym kontekście istotne było przyjęcie Deklaracji z Bangkoku z 1993 r., która jako pierwsza uwzględniła wartości azjatyckie w dokumencie o statusie międzynarodowym i podkreśliła ich istnienie oraz różnicę historyczną i kulturową w zakresie praw człowieka.

Prawa człowieka jako produkt cywilizacji zachodniej nie obejmują osiągnięć i myśli filozoficznej regionu Azji. Można przyjąć założenie, że prawa człowieka są uniwersalne nie dlatego, że dotyczą wszystkich ludzi i są powszechnie szanowane i uznawane - jak twierdzi większość zachodnich ekspertów - ale dlatego, że zostały włączone do konstytucji wielu państw azjatyckich (formalnie uznane). W tym sensie możemy mówić o pewnym uniwersalizmie praw człowieka.

Słowa kluczowe: prawa człowieka; wartości azjatyckie; Chiny; Japonia; Koreańska Republika Ludowo-Demokratyczna; Republika Korei. 